\title{
Effects of Zinc Glycinate on Growth Performance, Serum Biochemical Indexes, and Intestinal Morphology of Yellow Feather Broilers
}

\author{
Xiaoping Zhu ${ }^{1} \cdot$ Xiuguo Shang $^{1} \cdot$ Guozhao Lin ${ }^{1} \cdot$ Haojie $\mathrm{Li}^{1} \cdot$ Xin Feng $^{1} \cdot$ Huihua Zhang ${ }^{1}$ (I)
}

Received: 28 July 2021 / Accepted: 23 October 2021 / Published online: 5 November 2021

(c) The Author(s) 2021

\begin{abstract}
The purpose of this study was to investigate the effects of zinc glycinate (Gly-Zn) on growth performance, serum biochemical index, intestinal morphology, and hepatic metallothionein (MT) mRNA expression in the liver of yellow feather broilers. A total of 540 18-day-old yellow feather broilers were randomly divided into three groups: control group (basal diet), $\mathrm{ZnSO}_{4}$ group (basal diet plus $60 \mathrm{mg} \mathrm{Zn} / \mathrm{kg}$ from $\mathrm{ZnSO}_{4}$ ), and Gly-Zn group (basal diet plus $60 \mathrm{mg} \mathrm{Zn/kg}$ from zinc glycinate). Each treatment group had 6 replicates with 30 birds in each replicate. The experiment lasted for 42 days (18 to 59 days of age). The results showed that Gly-Zn supplementation significantly improved the average daily gain (ADG) and average daily feed intake (ADFI) of broilers during 18 to 39 days of age compared with that in the control group $(P<0.05)$ but not different from the $\mathrm{ZnSO}_{4}$ group. The Gly-Zn group had higher glutathione peroxidase (GSH-Px) $(P<0.05)$ and lower malondialdehyde (MDA) concentrations than the broilers in the control and $\mathrm{ZnSO} 4$ group. It was also observed that zinc content in the tibia of Gly-Zn group broilers was higher than the control and $\mathrm{ZnSO} 4$ group $(P<0.05)$. The results of intestinal morphology parameters showed that the Gly-Zn group significantly increased the villus height in duodenum and jejunum $(P<0.05)$ and decreased crypt depth in duodenum and ileum compared to the control group. However, there were no significant differences between the Gly- $\mathrm{Zn}$ group and $\mathrm{ZnSO}_{4}$ group in duodenum and ileum regarding intestinal morphology parameters. The Gly-Zn group significantly increased mRNA expression of MT in the liver than both control and $\mathrm{ZnSO}_{4}$ groups $(P<0.05)$. Collectively, the results indicated that supplementing $60 \mathrm{mg} \mathrm{Zn/kg} \mathrm{through} \mathrm{zinc} \mathrm{glycinate} \mathrm{improved} \mathrm{growth} \mathrm{performance}$ and serum indexes as well as intestinal morphology of yellow feather broilers. It also regulates MT gene expression more effectively than the $\mathrm{ZnSO}_{4}$ group at the transcriptional level.
\end{abstract}

Keywords Zinc glycinate $\cdot$ Yellow feather broiler · Growth performance $\cdot$ Serum index · Intestinal morphology · Metallothionein

\section{Introduction}

Zinc is a cofactor for more than 240 endogenous enzymes involved in the metabolism of proteins, lipids, carbohydrates, and nucleic acids. Animal growth, reproduction, immune regulation, and hormonal activity are all related to zinc [1-6]. NRC (1994) recommended that the amount of zinc added to broiler diets was $40 \mathrm{mg} / \mathrm{kg}$. Zinc is usually supplemented in the form of sulfate in animal diets due to

Xiaoping Zhu and Xiuguo Shang contributed equally to this work.

Huihua Zhang

hhzhang2@163.com

1 School of Life Science and Engineering, Foshan University, Foshan 528231, China the relatively low cost. However, the bioavailability of zinc in plant feed ingredients and conventional inorganic zinc sources (such as zinc sulfate and zinc oxide) is poor [7]. Furthermore, excessive addition of inorganic zinc in diets can cause serious environmental pollution.

Many studies have shown that the organic form of trace elements could prevent it from producing indigestible complexes with certain anti-nutritional compounds and mineral antagonist in the intestine [8]. Huang et al. $[9,10]$ showed that organic zinc has higher bioavailability than inorganic sources. Organic $\mathrm{Zn}$ could reduce negative environmental impact by decreasing manure zinc excretion. Amino acid chelated zinc could improve the performance of broilers and intestinal morphology, and optimize cecal microflora [11-13]. Metallothionein (MT) plays an important role in metabolism regulation 
and its expression is regulated by zinc level in the diet $[9,10]$. It can bind with $\mathrm{Zn}^{2+}$ and $\mathrm{Cu}^{2+}$ in plasma and be released when the body needs it. Therefore, the level of MT mRNA expression can be used as an effective marker to evaluate the zinc status in the body [11]. Additionally, Rao et al. found that supplementation of organic forms of $\mathrm{Zn}$ increased body mass gain and feed intake of broiler chicken compared to those fed the control diet [12]. However, limited information regarding whether organic $\mathrm{Zn}$ (zinc glycinate) regulates the growth performance of yellow feather broilers.

Therefore, the present study was set up to investigate the effects of zinc glycinate on the growth performance, intestinal morphology, and antioxidant status of yellow feather broilers. The findings of this study would provide valuable information for the selection and application of zinc supplements in broiler production.

\section{Materials and Methods}

\section{Diets and Zinc Sources}

The experiment diet was a corn-soybean-based pellet diet (Foshan Guangmuxing Feed Co., Ltd., Foshan, China), and the nutritional level of the diet for each stage refers to the nutritional requirements of Chinese yellow feather broiler (NY/T 33-2004). The diet composition and nutrient information are shown in Table 1. Zinc sulfate monohydrate (Zn, 34.5\%) and zinc glycinate (Zn, 21\%) were provided by Guangdong Xingtengke Biotechnology Co., Ltd. (Foshan, China).

\section{Experimental Design, Sampling, and Laboratory Analysis}

A total of 540 healthy (18 days old) broilers were randomly divided into three groups: control group (basal diet), $\mathrm{ZnSO}_{4}$ group (basal diet plus $60 \mathrm{mg} \mathrm{Zn/kg}$ from $\mathrm{ZnSO}_{4}$ ), and Gly$\mathrm{Zn}$ group (basal diet plus $60 \mathrm{mg} \mathrm{Zn} / \mathrm{kg}$ from zinc glycinate). There were six replicates per group and 30 chickens per replicate. All groups of chickens were kept under the same conditions with 23-h lighting from incandescent bulbs and free access to feed and water. The experiment lasted for 42 days. Before the study, the chicken house, cage, and feed trough were rinsed out and then disinfected. The temperature and relative humidity were controlled within the range of $24-26{ }^{\circ} \mathrm{C}$ and 85 to $90 \%$, respectively. The health status of the birds was monitored and the disease and mortality were recorded.

The body weight of broilers was measured at 18,40 , and 59 days of age, and average daily feed consumption was determined. The average daily feed intake (ADFI), average daily gain (ADG), and feed-to-weight ratio (F/G) were calculated. At 40 and 59 days of age, eighteen chickens from each group were randomly selected and $4 \mathrm{~mL}$ of the blood was collected from the wing vein. The blood samples were centrifuged at $3000 \mathrm{~g} / \mathrm{min}$ for $10 \mathrm{~min}$, and the supernatant was collected for later analysis. The albumin, total protein, malondialdehyde (MDA), and glutathione peroxidase (GSH-Px) were measured by enzyme-linked immunosorbent assay kits provided by Nanjing Jiancheng Bioengineering Research Institute (albumin, A028-2-1; total protein, A045-2-2; MDA, A003-1-2; GSH-Px, A005-1-2; Nanjing, China).

On the last day of the trial, three broilers were randomly selected from each replicate and slaughtered. The segments
Table 1 Composition and nutrient levels of the basal diet (air-dry basis, \%)

\begin{tabular}{lcclcc}
\hline Ingredients & 18-39 days & $40-59$ days & Nutrient levels ${ }^{2)}$ & $18-39$ days & 40-59 days \\
\hline Corn & 63.00 & 66.00 & $\mathrm{ME} /(\mathrm{MJ} / \mathrm{kg})$ & 12.76 & 13.37 \\
Soybean meal & 28.00 & 21.50 & $\mathrm{CP}$ & 19.00 & 17.00 \\
Corn gluten meal & 2.00 & 3.00 & $\mathrm{Lys}$ & 1.10 & 1.00 \\
Wheat middling & 0.17 & 0.23 & $\mathrm{Met}$ & 0.50 & 0.45 \\
Lard oil & 3.00 & 5.50 & $\mathrm{Zn}(\mathrm{mg} / \mathrm{kg})$ & 31.00 & 28.00 \\
Limestone & 1.32 & 1.32 & & & \\
Calcium hydrophosphate & 1.33 & 1.33 & & & \\
DL-Met & 0.18 & 0.12 & & & \\
Premix ${ }^{1)}$ & 1.00 & 1.00 & & & \\
Total & 100.00 & 100.00 & & & \\
\hline
\end{tabular}

${ }^{1)}$ The premix provided the following per kg of diets: VA $12000 \mathrm{IU}, \mathrm{VD}_{3} 5000 \mathrm{IU}, \mathrm{VB}_{2} 5 \mathrm{mg}, \mathrm{VK}_{3} 2 \mathrm{mg}$, VE $30 \mathrm{mg}, \mathrm{VB}_{1} 3 \mathrm{mg}, \mathrm{VB}_{12} 1 \mathrm{mg}$, nicotinic acid $3 \mathrm{~g}$, pantothenic acid $800 \mathrm{mg}$, folic acid $500 \mathrm{mg}$, biotin $0.2 \mathrm{mg}$, choline $500 \mathrm{mg}, \mathrm{Fe} 10 \mathrm{~g}, \mathrm{Cu} 8 \mathrm{~g}, \mathrm{Mn} 10 \mathrm{~g}, \mathrm{I} 42 \mathrm{mg}$, Se $30 \mathrm{mg}$

${ }^{2)} \mathrm{Zn}$ was a measured value, while the others were calculated values 
of duodenum, jujunum, and ileam were collected $(1 \mathrm{~cm})$. The intestinal samples were rinsed with cold phosphate buffer solution and fixed in 4\% formaldehyde solution for $24 \mathrm{~h}$, then embedded with paraffin, sliced, and stained. The length of the villi and the depth of the crypt were observed microscopically and measured.

The liver samples were sampled and stored at $-80{ }^{\circ} \mathrm{C}$ for later determination of expression of the hepatic metallothionein (MT-1) gene. Total RNA was extracted (TransGen Biotechnology Co., Ltd., Dalian, China) and $1 \mu \mathrm{g}$ RNA was reverse-transcribed into cDNA using the PrimeScript RT Reagent Kit (TaKaRa Biotechnology, Dalian, China) according to the manufacturer's guidelines. Quantitative real-time polymerase chain reaction (qRT-PCR) was performed on an ABI StepOnePlus ${ }^{\text {TM }}$ Real-Time PCR System (Applied Biosystems, Grand Island, NY, USA). The sequence of a primer used in this experiment was referred to Varum et al. [13] (forward 5'-AAG GGC TGT GTC TGC AAG GA-3', reverse 5'-CTT CAT CGG TAT GGA AGG TAC AA-3') and was synthesized by Shanghai Bioengineering Technology Co., Ltd (Shanghai, China). The relative mRNA expressions of target genes were calculated using the $2^{-\Delta \Delta C t}$ method as previously reported [14].

Two chickens were selected for each repeat 2 days before weighing. The excreta and daily feed intake of the selected chickens within $48 \mathrm{~h}$ were accurately recorded. Collect chicken manure every $2 \mathrm{~h}$, remove feathers, dandruff, and other sundries, and then put it into the dung box for weighing. Collection of ileal contents at slaughter on the last day of the trial. The ileal contents and excreta samples collected from each chicken were dried at $65{ }^{\circ} \mathrm{C}$ for $48-72 \mathrm{~h}$, then recovered at room temperature for $24 \mathrm{~h}$, and crushed. The tibia, intestinal segment, and feces were crushed, dried at $65^{\circ} \mathrm{C}$ for $12 \mathrm{~h}$, dried at $105^{\circ} \mathrm{C}$ to constant weight, returned to moisture at room temperature for $12 \mathrm{~h}$, and then crushed again. We weigh $2.0 \mathrm{~g}$ of the crushed sample into a crucible, carbonize the sample to smokeless in an electric furnace, cool it to normal temperature, then ash it in a high-temperature electric furnace at $500-550{ }^{\circ} \mathrm{C}$ for $8 \mathrm{~h}$, cool it to normal temperature, add $2 \mathrm{~mL}$ of $1 \mathrm{~mol} / \mathrm{L}$ nitric acid, bake in an oven at $35{ }^{\circ} \mathrm{C}$ overnight, and then transfer the solution to a $50-\mathrm{mL}$ volumetric flask for constant volume. The content of zinc in the sample was determined by Ice-3500 atomic absorption spectrometry (Thermo Fisher Scientific, Waltham, USA).

\section{Statistical Analysis}

The data was analyzed by using the one-way ANOVA in SPSS (24.0). The treatment effects were included in the model as fixed effects. Multiple comparisons were performed using Duncan's method. The difference was declared significant at $P<0.05$ and highly significant at $P<0.01$. The results were expressed as "mean \pm mean standard error."

\section{Results and Discussion}

\section{Growth Performance}

The effect of zinc supplementation on the growth performance of yellow feather broilers is presented in Table 2 . At 40 days of age, the broilers from the Gly-Zn groups had higher body weight compared to the control groups but not different from the $\mathrm{ZnSO} 4$ group broilers. The average daily gain (ADG) and average daily feed intake (ADFI) of GlyZn group broilers were significantly higher than that of the control group between 18 and $39(P<0.05)$, but had no difference compared with the $\mathrm{ZnSO}_{4}$ group. The feed-to-weight ratio $(\mathrm{F} / \mathrm{W})$ of the Gly-Zn group was lower than the control
Table 2 Effects of zinc supplementation on the growth performance of yellowfeathered broilers

\begin{tabular}{llllrrr}
\hline & & Control & $\mathrm{ZnSO}_{4}$ & Gly-Zn & SEM & $P$-value \\
\hline BW (40 days) & & $818.21^{\mathrm{b}}$ & $822.22^{\mathrm{ab}}$ & $840.83^{\mathrm{a}}$ & 6.72 & 0.042 \\
BW (59 days) & & 1486.80 & 1488.59 & 1526.35 & 16.43 & 0.083 \\
$18-39$ days & ADFI (g) & $54.05^{\mathrm{b}}$ & $54.67^{\mathrm{ab}}$ & $56.19^{\mathrm{a}}$ & 0.06 & 0.032 \\
& ADG (g) & $26.39^{\mathrm{b}}$ & $26.54^{\mathrm{ab}}$ & $27.41^{\mathrm{a}}$ & 0.03 & 0.025 \\
& F/W & 2.04 & 2.05 & 2.05 & 0.01 & 0.084 \\
$40-59$ days & ADFI (g) & 83.17 & 82.78 & 83.30 & 0.46 & 0.156 \\
& ADG (g) & 35.18 & 35.07 & 36.07 & 0.54 & 0.183 \\
& F/W & 2.36 & 2.36 & 2.31 & 0.03 & 0.261 \\
$18-59$ days & ADFI (g) & 68.99 & 69.05 & 70.28 & 1.46 & 0.336 \\
& ADG (g) & 30.35 & 30.59 & 31.42 & 1.02 & 0.421 \\
& F/W & $2.27^{\mathrm{a}}$ & $2.25^{\mathrm{ab}}$ & $2.22^{\mathrm{b}}$ & 0.01 & 0.023 \\
\hline
\end{tabular}

There are three treatments, control, a basal diet; ZnSO4, a basal diet plus ZnSO4; Gly-Zn, a basal diet plus zinc glycinate. $n=6 /$ treatment. ${ }^{\text {a,b,c }}$ Values labeled with different superscripts in the same row differ significantly $(p<0.05)$ 
group during the whole study period but not different from that of the $\mathrm{ZnSO}_{4}$ group.

Zinc can promote the feed intake and weight gain of animals by promoting the rapid proliferation of taste bud cells in tongue mucosa, prolonging the residence time of feed in the digestive tract, and improving the secretion of the digestive system and the activity of enzymes in tissue cell $[15,16]$. Many studies have shown that organic zinc is more effective than inorganic zinc in improving the feed intake and daily gain of broilers, shown by reduced feed conversion rate and improved economic benefits. However, in our study, there was no difference detected between the inorganic zinc group $\left(\mathrm{ZnSO}_{4}\right)$ and the zinc glycinate (Gly$\mathrm{Zn})$ group. Aoyagi and Baker [17] reported that corn-soybean-type diets supplemented with lysine zinc significantly increased feed conversion in broilers. Star et al. [18] found that compared with inorganic zinc, organic zinc would significantly increase the feed intake of hens and reduce the feed-to-weight ratio. But, these were not observed in our study. This might be caused by the difference in breeds, diet, and environment.

\section{Blood Parameters and Zinc Content}

The effects of zinc supplementation on blood parameters and $\mathrm{Zn}$ concentration of yellow feather broilers are presented in Table 3. The serum total protein and albumin of the Gly$\mathrm{Zn}$ group was significantly higher than the control group $(P<0.05)$, but not different from the $\mathrm{ZnSO}_{4}$ group. Serum albumin was increased by $28.28 \%(P<0.05)$ in the Gly- $\mathrm{Zn}$ group compared with the control group at 59 days of age. The Gly-Zn group had a lower concentration of MDA than both the control and $\mathrm{ZnSO}_{4}$ group but higher in terms of $\mathrm{Zn}$ content in the tibia $(P<0.05)$. The Gly- $Z n$ group significantly improved the concentration of $\mathrm{Zn}$ in feces and ileum contents compared with the control group $(P<0.05)$. Higher serum total protein content indicates that the body's protein metabolism was well balanced, which was beneficial to the absorption and utilization of protein $[19,20]$. Kucuk et al. [21] reported that supplement with $\mathrm{ZnSO}_{4}$ significantly increased the protein concentration in the serum of broilers. Our results were consistent with Kucuk's findings. Yu et al. [22] added organic zinc (zinc methionine) and inorganic zinc (zinc sulfate) to broiler diets and found that the plasma total zinc and albumin contents in the organic zinc group were higher than those in the inorganic zinc groups. Abedini et al. [23] showed that the supplementation with $\mathrm{Zn}$ significantly affected serum total protein and albumin concentrations in comparison with the control. Prasad [24] reported that $\mathrm{Zn}$ deficiency may cause abnormalities in nucleic acid synthesis and the activity of many enzymes. In the present study, our results showed that supplemented with $\mathrm{Zn}$ increased serum proteins, but there was no difference between organic zinc and inorganic zinc on serum protein.

GSH-Px is an enzyme that removes $\mathrm{H}_{2} \mathrm{O}_{2}$ and organic peroxides from living organisms, prevents lipid peroxides from damaging body tissues and biofilms, and averts from further hydrolysis of lipid peroxides into harmful substances MDA. The MDA concentration in the body can indirectly reflect the oxygen free radical metabolism in the body, the degree of free radical attack of the body tissue cells, and the degree of lipid peroxidation. Many studies have explored the relationship between zinc and antioxidant indexes. A study by De Grande et al. [16] showed that supplementation with Zn-AA complexes alleviated oxidative stress indicated by decreased MDA plasma levels and GSH-Px activities. Previous studies indicated that zinc source and zinc levels significantly affected GSH-Px activity and effectively reduced MDA content [25-27]. Ma et al. [11] suggested that zinc supplementation could decrease MDA levels in the liver compared to the control group, which confirms the importance of zinc supplementation in broilers. Fathi et al. [28] suggested that different zinc sources had different effects on the antioxidant activity of broilers by regulating the GSHPx and MDA contents. Similarly, the results of the current study showed that organic zinc supplementation significantly improved GSH-Px content and decreased MDA content in the early stage of the yellow-feathered broiler.

Zinc supplement clearly increases fecal $\mathrm{Zn}$ excretion and $\mathrm{Zn}$ concentration ileum content in our study, which is consistent with previous studies' results [29]. Zinc can improve bone formation by stimulating cell proliferation, collagen synthesis in osteoblastic cells, and mineralization [30-32]. Zn had also an effect on the mechanical properties of bones [33]. Bone strength and bone zinc content were easily affected by the amount of zinc added to the diet. Sandoval et al. [34] found that the zinc content of the tibia increased with the zinc levels of supplementation. Shelton and Southern reported that the breaking strength of the tibia increased significantly over 14 days on a diet supplemented with $75 \mathrm{ppm} \mathrm{Zn} \mathrm{[35].} \mathrm{In} \mathrm{addition,} \mathrm{the} \mathrm{content} \mathrm{of} \mathrm{zinc} \mathrm{in}$ the bone was influenced by the types of zinc added to the diets. Kwiecień et al. observed that the addition of Zn-Gly increased the accumulation of $\mathrm{Zn}$ both in the tibia and in the femur of the birds compared with $\mathrm{Zn}_{-} \mathrm{SO}_{4}$ [36]. In a study investigating the bioavailability of $\mathrm{ZnSO}_{4}$ and methionine zinc, the experiment results showed that the zinc content of the tibia of broilers in the methionine zinc group was higher than that in the $\mathrm{ZnSO}_{4}$ group [37]. Wedekind et al. [38] also found that zinc methionine could significantly increase the zinc content of the cavity bone compared with $\mathrm{ZnSO}_{4}$ and $\mathrm{ZnO}$. Alkhtib et al. [39] reported a significant increase in tibia strength associated with feeding the chelated zinc or M-Nano-Zn supplements compared with $\mathrm{ZnSO}_{4}$ at 21 days post-hatch. In our study, the Gly-Zn group had higher tibia 


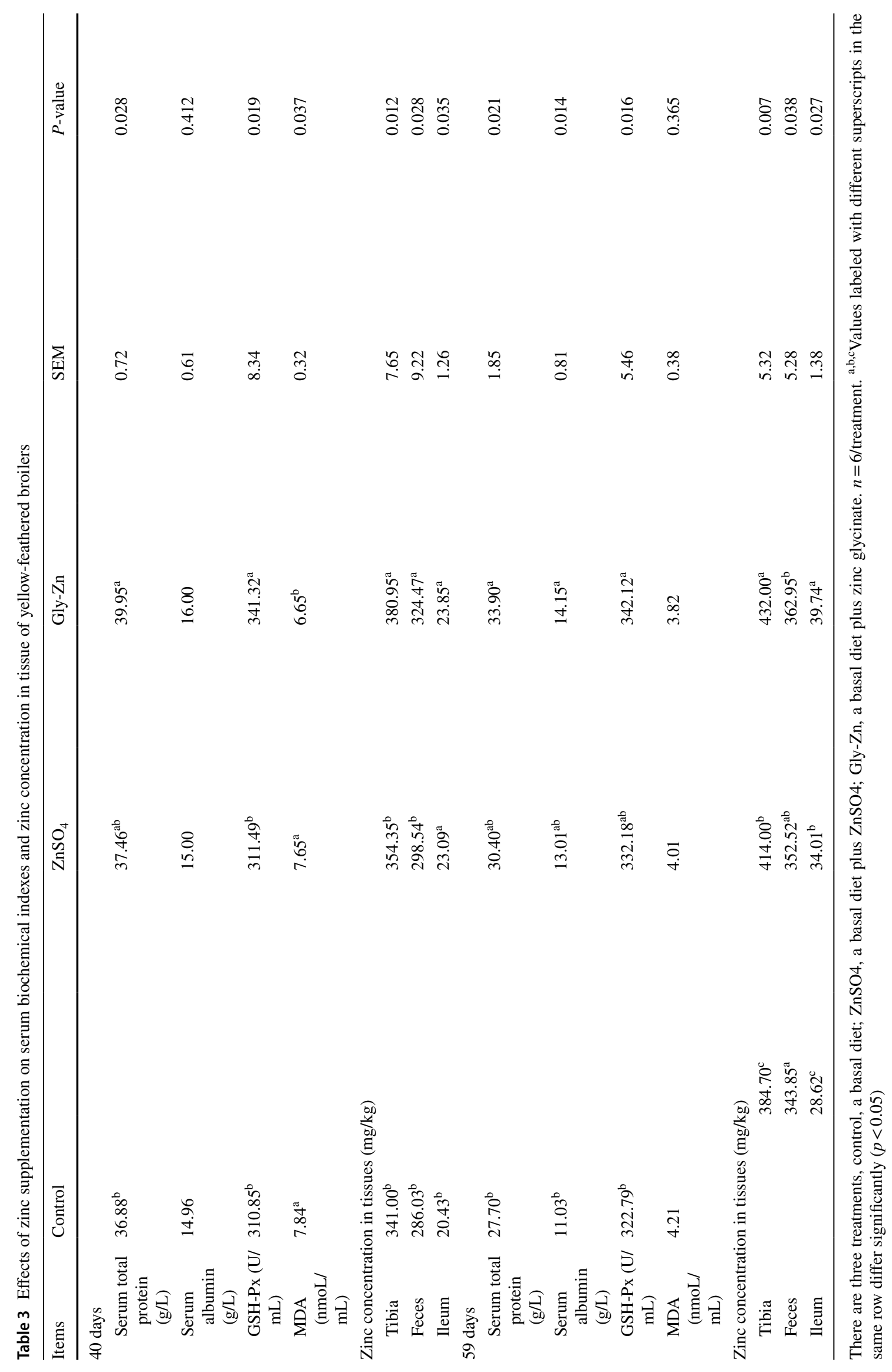


$\mathrm{Zn}$ content compared with the $\mathrm{ZnSO}_{4}$ group indicating that the organic zinc might have higher bioavailability. According to the present study, the use of Zn-Gly contributed to improving the quality of the tibia and the femur and their strength parameters, perhaps due to the increased deposition of $\mathrm{Ca}$ and $\mathrm{P}$ in bones.

\section{Intestinal Morphology}

The effects of zinc supplementation on small intestine morphology and structure of yellow feather broilers are presented in Table 4. The villi height and ratio of villus height to crypt depth of duodenum and jejunum of the Gly- $\mathrm{Zn}$ group were higher than the control group but no difference compared with the $\mathrm{ZnSO}_{4}$ group $(P<0.05)$. In the ileum, the Gly-Zn group had lower crypt depth and a higher ratio of villus height to crypt depth compared to the control group and the $\mathrm{ZnSO}_{4}$ groups $(P<0.05)$.

The small intestine is an important location for the absorption of nutrients in the animal's body. The villus height of the small intestine and the crypt depth are important indicators for assessing the digestion and absorption capacity of the small intestine. Ewtushik et al. [40] had shown that with the villus height of the small intestine increasing, the number of epithelial cells was also increased, and the ability to absorb nutrients in the gastrointestinal tract enhanced. The depth of crypts reflects the maturity and rate of increase of epithelial cells. As the crypts become shallower, the nutrient absorption capacity is enhanced. The ratio between villus height and crypt depth reflects the absorption capacity of the small intestine, and the absorption capacity of the small intestine increases as the ratio increases [41]. Park et al. [42] found that dietary zinc supplementation would effectively improve the intestinal villus height of weaned piglets, reduce the depth of crypts, and improve health condition. De Grande et al. [16] showed that compared with inorganic zinc, zinc amino acid in broilers' feed was more easily absorbed and could protect villous epithelial cells at the initial stage. On the 10th and 28th days, the villus length of broilers supplemented with zinc amino acid complex significantly increased. Li et al. [43] results indicated that $80 \mathrm{mg} / \mathrm{kg}$ Zn-Met supplementation increased villus height, villus area, and villus height/crypt depth ratio and reduced crypt depth in the jejunum of laying hens compared with the control and $\mathrm{ZnSO} 4$ group. In this study, the Gly-Zn group broiler had higher villus height and lower crypt depth in the duodenum and jejunum than the control group broilers but was not different from the $\mathrm{ZnSO}_{4}$ group broilers. In the ileum, the Gly-Zn group broiler had lower crypt depth and a higher ratio of villus height to crypt depth compared to the control and $\mathrm{ZnSO}_{4}$ group, which indicated that the superiority of organic zinc than the inorganic zinc source.

\section{MT mRNA Expression}

The effects of different zinc supplementations on MT mRNA expressions in livers of yellow feather broilers are presented in Fig. 1. The hepatic MT mRNA expression of the Gly-Zn group was significantly higher than the control group and $\mathrm{ZnSO}_{4}$ group $(P<0.05)$. Zinc can effectively regulate MT gene expression at the transcriptional level [44-46]. Wang et al. [47] found that MT concentrations in the liver and pancreas of broilers supplemented with organic zinc were significantly higher than those in the control group. Different zinc sources also have an important effect on the expression of MT mRNA. Cao et al. [48] also showed that organic Zn sources with moderate or strong complex strength slightly upregulated the MT protein level in the intestine of broilers, compared with the inorganic $\mathrm{Zn}$ source. A previous study showed that on day 28 , metallothionein (MT) mRNA levels in the duodenum, jejunum, and ileum were enhanced
Table 4 Effects of zinc supplementation on intestinal morphology of yellow-feathered broilers

\begin{tabular}{lllllll}
\hline Item & & Control & $\mathrm{ZnSO}_{4}$ & Gly-Zn & SEM & $P$-value \\
\hline Duodenum & Villus height $(\mu \mathrm{m})$ & $1377.40^{\mathrm{b}}$ & $1448.66^{\mathrm{ab}}$ & $1477.27^{\mathrm{a}}$ & 29.22 & 0.036 \\
& Crypt depth $(\mu \mathrm{m})$ & $223.02^{\mathrm{a}}$ & $194.05^{\mathrm{b}}$ & $193.97^{\mathrm{b}}$ & 8.26 & 0.021 \\
& $V^{1} / C^{1}$ & $6.29^{\mathrm{b}}$ & $7.59^{\mathrm{ab}}$ & $8.02^{\mathrm{a}}$ & 0.51 & 0.019 \\
\multirow{3}{*}{ Jejunum } & Villus height $(\mu \mathrm{m})$ & $1112.96^{\mathrm{b}}$ & $1139.15^{\mathrm{ab}}$ & $1174.09^{\mathrm{a}}$ & 16.46 & 0.028 \\
& Crypt depth $(\mu \mathrm{m})$ & 175.91 & 162.94 & 157.20 & 11.26 & 0.241 \\
& V/C & $6.40^{\mathrm{b}}$ & $7.04^{\mathrm{ab}}$ & $7.59^{\mathrm{a}}$ & 0.33 & 0.039 \\
& Vileum & 1172.34 & 1179.77 & 1247.95 & 32.11 & 0.279 \\
& Crypt depth $(\mu \mathrm{m})$ & $204.33^{\mathrm{a}}$ & $208.44^{\mathrm{a}}$ & $150.00^{\mathrm{b}}$ & 12.67 & 0.034 \\
& V/C & $6.04^{\mathrm{b}}$ & $6.65^{\mathrm{b}}$ & $8.53^{\mathrm{a}}$ & 0.62 & 0.023 \\
\hline
\end{tabular}

There are three treatments, control, a basal diet; ZnSO4, a basal diet plus ZnSO4; Gly-Zn, a basal diet plus zinc glycinate. $n=6 /$ treatment. ${ }^{\text {a,b,c }}$ Values labeled with different superscripts in the same row differ significantly $(p<0.05)$

${ }^{1)} \mathrm{V} / \mathrm{C}$ means villus height/crypt depth ratio 
Fig. 1 Effects of different zinc supplementation on MT mRNA expression in livers of yellow-feathered broilers. There are three treatments, control, a basal diet; $\mathrm{ZnSO} 4$, a basal diet plus ZnSO4; Gly-Zn, a basal diet plus zinc glycinate; $n=6$ / treatment

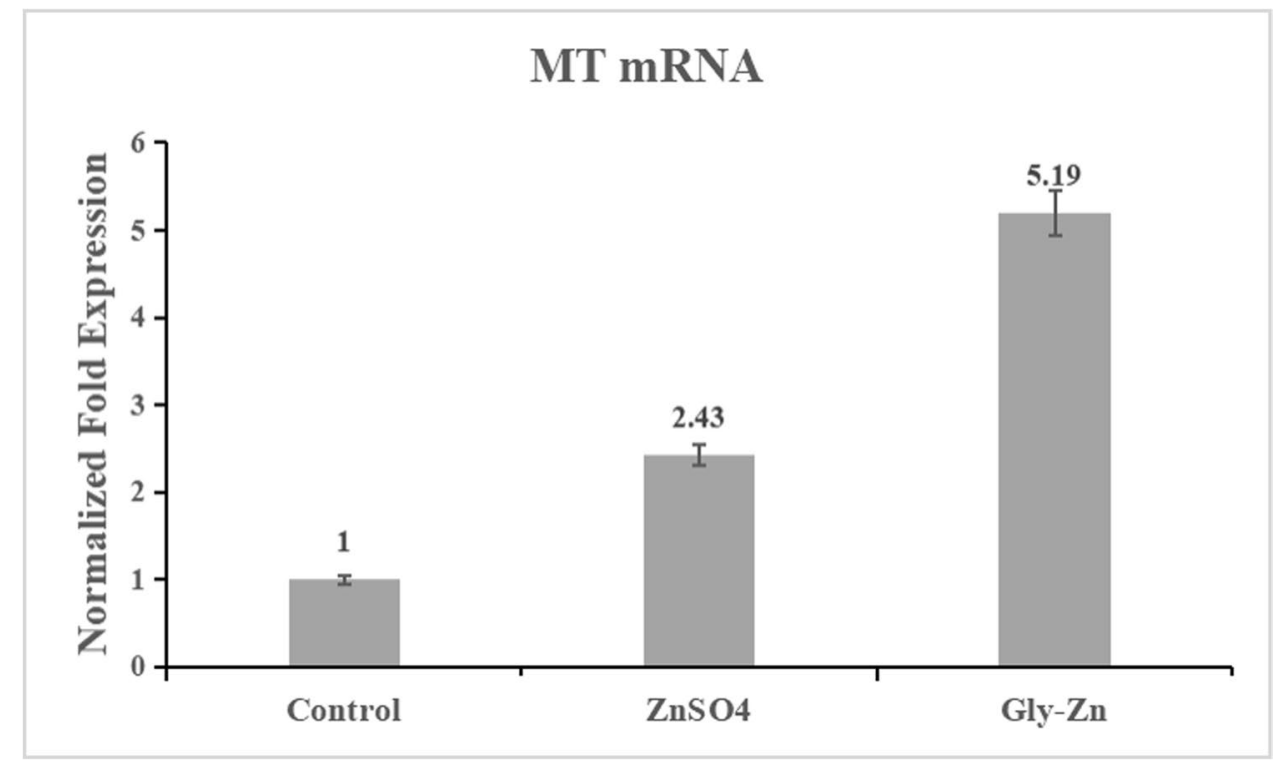

$(P<0.05)$ with $\mathrm{Zn}$ addition regardless of $\mathrm{Zn}$ source [49]. These were also observed in the current study as there were significant differences between the Gly-Zn group and the $\mathrm{ZnSO}_{4}$ group, which indicated that organic zinc could have more effective regulation for MT gene expression than inorganic zinc at the transcriptional level.

\section{Conclusions}

Supplementation of $60 \mathrm{mg} \mathrm{Zn/kg}$ in the form of zinc glycinate to the corn-soybean-based diet resulted in better growth performance of the yellow-feathered broilers. Compared to $\mathrm{ZnSO}_{4}$, zinc glycinate improved the antioxidant status, increased the tibia $\mathrm{Zn}$ content, and had more effective regulation for MT gene expression at the transcriptional level.

Acknowledgements We sincerely acknowledge Guangdong Xingtengke Biotechnology Co., Ltd., for experimental material assistance and Foshan University for providing the animal experimental site.

Author Contribution Xiuguo Shang and Huihua Zhang designed the conceptualization and methodology of the experiment; Xin Feng provided helpful suggestions and statistical analysis of all data; Xiaoping Zhu wrote the original draft and modified it; Haojie Li and Guozhao Lin conducted the animal feeding, the sample collection, and analysis.

Funding This research was supported by the Innovation Team Construction Project of the Poultry Industry Technology System of Modern Agriculture in Guangdong Province (grant number 2019KJ28), Scientific Research Foundation in the Higher Education Institutions of Educational Commission of Guangdong Province (grant number 2017GCZX006), and Discipline Construction Program of Foshan University ( grant number CGZ0400162).

Data Availability The data used to support the findings are all included in the article.

\section{Declarations}

Ethics Approval All experimental procedures referring to the animals were approved by the Animal Care Use Committee of Foshan University, which were in accordance with ethical standards in Laboratory animal-guideline for ethical review of animal welfare (The National Standard of the People's Republic of China GB/T 35892-2018).

Conflict of Interest The authors declare no competing interests.

Open Access This article is licensed under a Creative Commons Attribution 4.0 International License, which permits use, sharing, adaptation, distribution and reproduction in any medium or format, as long as you give appropriate credit to the original author(s) and the source, provide a link to the Creative Commons licence, and indicate if changes were made. The images or other third party material in this article are included in the article's Creative Commons licence, unless indicated otherwise in a credit line to the material. If material is not included in the article's Creative Commons licence and your intended use is not permitted by statutory regulation or exceeds the permitted use, you will need to obtain permission directly from the copyright holder. To view a copy of this licence, visit http://creativecommons.org/licenses/by/4.0/.

\section{References}

1. Manangi MK, Vazquez-Anon M, Richards JD, Carter S, Buresh RE, Christensen KD (2012) Impact of feeding lower levels of chelated trace minerals versus industry levels of inorganic trace minerals on broiler performance, yield, footpad health, and litter mineral concentration. J Appl Poult Res 21(4):881-890. https:// doi.org/10.3382/japr.2012-00531

2. Shankar AH, Prasad AS (1998) Zinc and immune function: the biological basis of altered resistance to infection. Am J Clin Nutr 68(2 Suppl):447S-463S. https://doi.org/10.1093/ajcn/68.2.447S

3. Liu ZH, Lu L, Wang RL, Lei HL, Li SF, Luo ZLY, XG, (2015) Effects of supplemental zinc source and level on antioxidant ability and fat metabolism-related enzymes of broilers. Poult Sci 94(11):2686-2694. https://doi.org/10.3382/ps/pev251 
4. Naz S, Idris M, Khalique MA, Rahman ZU, Alhidary IA, Abdelrahman MM, Khan RU, Chand N, Farooq U, Ahmad S (2016) The activity and use of zinc in poultry diets. World's Poult Sci J 72(1):159-167. https://doi.org/10.1017/S0043933916000155

5. Perez V, Shanmugasundaram R, Sifri M, Parr TM, Selvaraj RK (2017) Effects of hydroxychloride and sulfate form of zinc and manganese supplementation on superoxide dismutase activity and immune responses post lipopolysaccharide challenge in poultry fed marginally lower doses of zinc and manganese. Poult Sci 96(12):4200-4207. https://doi.org/10.3382/ps/pex244

6. Sloup V, Jankovská I, Nechybová S, Perinková P, Lan-grová I (2017) Zinc in the animal organism: a review. Sci Agric Bohem 48(1):13-21. https://doi.org/10.1515/sab-2017-0003

7. Fordyce EJ, Forbes RM, Robbins KR, Erdman JW (1987) Phytate $\times$ calcium/zinc molar ratios: are they predictive of zinc bioavailability? Food Sci 52(2):440-444. https://doi.org/10. 1111/j.1365-2621.1987.tb06634.x

8. Swiatkiewicz S, Arczewska-Wlosek A, Jozefiak D (2014) The efficacy of organic minerals in poultry nutrition: review and implications of recent studies. World's Poult Sci J 70(3):475486. https://doi.org/10.1017/S00439339140000531

9. Huang YL, Lu LG, Li SF, Luo XG (2009) Relative bioavailabilities of organic zinc sources with different chelation strengths for broilers fed a conventional corn soybean meal diet. J Anim Sci 87(6):2038-2046. https://doi.org/10.2527/jas.2008-1212

10. Huang YL, Lu LG, Xie JJ, Li LSF, XL, Liu SB, Zhang LY, Xi L, Luo XG, (2013) Relative bioavailabilities of organic zinc sources with different chelation strengths for broilers fed diets with low or high phytate content. Anim Feed Sci Tech 179(1):144-148. https://doi.org/10.1016/j.anifeedsci.2012.10. 010

11. Ma W, Niu HH, Feng J, Wang Y, Feng J (2011) Effects of zinc glycine chelate on oxidative stress, contents of trace elements, and intestinal morphology in broilers. Biol Trace Elem Res 142(3):546-556. https://doi.org/10.1007/s12011-010-8824-9

12. Rao RS, Prakash VB, Raju MVL, Panda NAK, Kumari RK, Reddy EPK (2016) Effect of supplementing organic forms of zinc, selenium and chromium on performance, anti-oxidant and immune responses in broiler chicken reared in tropical summer. Biol Trace Elem Res 172(1):511-520. https://doi.org/10.1007/ s12011-015-0587-x

13. Varun A, Karthikeyan N, Muthusamy P, Raja A (2017) Real time PCR based expression of metallothionein and evaluation of $\mathrm{Zn}$ bioavailability in chickens fed zinc oxide and zinc methionine. Inte J Curr Micro Appl Sci 6(7):845-849. https://doi.org/ 10.20546/ijcmas.2017.607.103

14. Livak KJ, Schmittgen TD (2001) Analysis of relative gene expression data using real-time quantitative PCR and the $2^{-\Delta \Delta C t}$ method. Methods 25(4):402-408. https://doi.org/10.1006/meth. 2001.1262

15. Jahanian R, Rasouli E (2015) Effects of dietary substitution of zinc-methionine for inorganic zinc sources on growth performance, tissue zinc accumulation and some blood parameters in broiler chicks. J Anim Physiol Anim Nutri 99(1):50-58. https:// doi.org/10.1111/jpn.12213

16. Grande AD, Leleu S, Delezie E, Rapp C, Smet SD, Goossens E, Haesebrouck F, Immerseel FV (2020) Dietary zinc source impacts intestinal morphology and oxidative stress in young broilers. Poult Sci 99(1):441-453. https://doi.org/10.3382/ps/pez525

17. Aoyagi S, Baker DH (1993) Nutritional evaluation of copperlysine and zinc-lysine complexes for chicks. Poult Sci 72(1):165171. https://doi.org/10.3382/ps.0720165

18. Star L, van der Klis JD, Rapp C, Ward TL (2012) Bioavailability of organic and inorganic zinc sources in male broilers. Poult Sci 91(12):3115-3120. https://doi.org/10.3382/ps.2012-02314
19. Baldi A, Bontempo V, Dell'Orto V, Cheli F, Savoini G (1999) Effects of dietary chromium-yeast in weaning-stressed piglets. Canadian J Anim Sci 79(3):369-374. https://doi.org/10.4141/ A98-117

20. Sun H, Ye YB, Wu YF, Wang X, Liu Y, Tang J (2014) Effects of partial replacement of fish meal by fermented cottonseed meal on growth performance, body composition and plasma biochemical indices of juvenile black sea bream. Chin J Anim Nutri 26(5):1238-1245. https://doi.org/10.3969/j.issn.1006-267x.2014. 05.014

21. Kucuk O, Sahin N, Sahin K (2003) Supplemental zinc and vitamin A can alleviate negative effects of heat stress in broiler chickens. Biol Trace Elem Res 94(3):225-235. https://doi.org/10.1385/ BTER:94:3:225

22. Yu Y, Lu L, Li SF, Zhang LY, Luo XG (2017) Organic zinc absorption by the intestine of broilers in vivo. Br J Nutr 117(8):1086-1094. https://doi.org/10.1017/S0007114517001040

23. Abedini M, Shariatmadari F, Karimi Torshizi MA, Ahmadi H (2018) Effects of zinc oxide nanoparticles on the egg quality, immune response, zinc retention, and blood parameters of laying hens in the late phase of production. Anim Phy and Anim Nutr 102(3):736-745. https://doi.org/10.1111/jpn.12871

24. Prasad AS (2014) Zinc: an antioxidant and anti-inflammatory agent: role of zinc in degenerative disorders of aging. J Trace Elem Med Bio 28(4):364-371. https://doi.org/10.1016/j.jtemb. 2014.07.019

25. Li LL, Gong YJ, Zhan HQ, Zheng YX, Zou XT (2018) Effects of dietary Zn-methionine supplementation on the laying performance, egg quality, antioxidant capacity, and serum parameters of laying hens. Poult Sci 98(2):923-931. https://doi.org/10.3382/ ps/pey440

26. Wen M, Wu B, Zhao H, Liu G, Chen X, Tian G, Cai J, Jia G (2019) Effects of dietary zinc on carcass traits, meat quality, antioxidant status, and tissue zinc accumulation of Pekin ducks. Biol Trace Elem Res 190(1):187-196. https://doi.org/10.1007/ s12011-018-1534-4

27. Yan JY, Zhang GW, Zhang C, Tang L, Kuang SY (2017) Effects of diarrhoea, serum and tissue zinc concentrations, and intestinal morphology in growing rabbit. World Rabbit Sci 25(1):43. https:// doi.org/10.4995/wrs.2017.5770

28. Fathi M, Haydari M, Tanha T (2016) Effects of zinc oxide nanoparticles on antioxidant status, serum enzymes activities, biochemical parameters and performance in broiler chickens. J Live Sci Tech 4(2):07-13. https://doi.org/10.22103/JLST.2016.1509

29. Meyer TA, Lindemann MD, Gromwell GL, Monegue HL (2002) Effects of pharmacological levels of zinc as zinc oxide on fecal zinc and mineral excretion in weanling pigs. Profess Anim Scientist 18(2):162-168. https://doi.org/10.15232/S1080-7446(15) 31506-0

30 Yamaguchi M, Yamaguchi R (1986) Action of zinc on bone metabolism in rats. Increases in alkaline phosphatase activity and DNA content. Biochem Pharmacol 35(5):773-777. https://doi.org/ 10.1016/0006-2952(86)90245-5

31. Mwangi S, Timmons J, Ao T, Paul M, Macalintal L, Pescatore A, Cantor A, Ford M, Dawson KA (2017) Effect of zinc imprinting and replacing inorganic zinc with organic zinc on early performance of broiler chicks. Poult Sci 96(4):861-868. https://doi.org/ $10.3382 / \mathrm{ps} /$ pew312

32. Seo H, Cho Y, Kim T, Shin H, Kwun I (2010) Zinc may increase bone formation through stimulating cell proliferation, alkaline phosphatase activity and collagen synthesis in osteoblastic MC3T3-E1 cells. Nutr Res Pract 4(5):356-361. https://doi.org/ 10.4162/nrp.2010.4.5.356

33. Tomaszewska E, Dobrowolski P, Kwiecień M, Winiarska-Mieczan A, Wawrzyniak A, Burmańczuk N (2016) Influence of organic zinc diet in low level on bone development in male Ross broiler 
chickens. Ann Anim Sci 16(2):507-519. https://doi.org/10.1515/ aoas-2015-0087

34. Sandoval MJ, Henry PR, Ammerman CB, Miles RD (1997) Relative bioavailability of supplemental inorganic zinc sources for chicks. J Anim Sci 75(12):3195-3205. https://doi.org/10.2527/ 1997.75123195x

35. Shelton JL, Southern LL (2007) Interactive effect of zinc, copper and manganese in diets for broilers. Int J Poult Sci 6(7):466-469. https://doi.org/10.3923/ijps.2007.466.469

36. Kwiecień M, Winiarska-Mieczan A, Milczarek A, Tomaszewska E, Matras J (2016) Effects of zinc glycine chelate on growth performance, carcass characteristics, bone quality, and mineral content in bone of broiler chicken. Livestock Sci 191(6):43-50. https://doi.org/10.1016/j.livsci.2016.07.005

37. Ao T, Pierce JL, Power R, Pescatore AJ, Cantor AH, Dawson KA, Ford MJ (2009) Effects of feeding different forms of zinc and copper on the performance and tissue mineral content of chicks. Poult Sci 88(10):2171-2175. https://doi.org/10.3382/ps.2009-00117

38. Wedekind KJ, Hortin AE, Baker DH (1992) Methodology for assessing zinc bioavailability: efficacy estimates for zinc-methionine, zinc sulfate, and zinc oxide. J Anim Sci 70(1):178-187. https://doi.org/10.2527/1992.701178x

39. Alkhtib A, Scholey D, Carter N, Cave G, Hanafy B, Kempster SRJ, Mekapothula SR, Roxborough ET, Burton EJ (2020) Bioavailability of methionine-coated zinc nanoparticles as a dietary supplement leads to improved performance and bone strength in broiler chicken production. Animals 10(9):1482-1494. https://doi. org/10.3390/ani10091482

40. Ewtushik AL, Bertolo RFP, Ball RO (2000) Intestinal development of early-weaned piglets receiving diets supplemented with selected amino acids or polyamines. Can J Anim Sci 80(4):653662. https://doi.org/10.4141/A99-134

41. Liu H, Wang J, Mou D, Che L, Fang Z, Feng B, Lin Y, Xu S, Li J, Wu D (2017) Maternal methyl donor supplementation during gestation counteracts the bisphenol A-induced impairment of intestinal morphology, disaccharidase activity, and nutrient transporters gene expression in newborn and weaning pigs. Nutrients 9(5):423-437. https://doi.org/10.3390/nu9050423

42. Park BC, Jung DY, Kang SY, Ko YH (2014) Effects of dietary supplementation of a zinc oxide product encapsulated with lipid on growth performance, intestinal morphology, and digestive enzyme activities in weanling pigs. Anim Feed Sci Tech 200(1):112-117. https://doi.org/10.1016/j.anifeedsci.2014.11.016

43. Li LL, Li HY, Zhou WT, Feng J, Zou XT (2019) Effects of zinc-methionine supplementation on laying performance, zinc status, intestinal morphology, and expressions of zinc transporters mRNA in laying hens. J Sci Food Agric 99(14):6582-6588. https://doi.org/10.1002/jsfa.9941

44. Palmiter RD (1998) The elusive function of metallothioneins. Proc Natl Acad Sci USA 95(15):8428-8430. https://doi.org/10.1073/ pnas. 95.15 .8428

45. Cousins RJ, Lee-ambrose LM (1992) Nuclear zinc uptake and interactions and metallothionein gene expression are influenced by dietary zinc in rat. J Nutri 122(1):56-64. https://doi.org/10. 1093/jn/122.1.56

46. Davis SR, Cousins RJ (2000) Metallothionein expression in animals: a physiological perspective on function. J Nutr 130(5):10851088. https://doi.org/10.1093/jn/130.5.1085

47. Wang ZC, Yu HM, Xie JJ, Cui H, Nie H, Zhang TT, Gao XH (2019) Effect of dietary zinc pectin oligosaccharides chelate on growth performance, enzyme activities, $\mathrm{Zn}$ accumulation, metallothionein concentration, and gene expression of $\mathrm{Zn}$ transporters in broiler chickens. J Anim Sci 97(5):2114-2124. https://doi.org/ 10.1093/jas/skz038

48. Cao J, Henry PR, Davis SR, Cousins RJ, Littell RC, Miles RD, Ammerman CB (2002) Relative bioavailability of organic zinc sources based on tissue zinc and metallothionein in chicks fed conventional dietary zinc concentrations. Anim Feed Sci Tech 101(1):161-170. https://doi.org/10.1016/S0377-8401(02)00051-2

49. Andrews GK, Geiser J (1999) Expression of the mouse metallothionein-I and -II genes provides a reproductive advantage during maternal dietary zinc deficiency. J Nutr 129(9):1643-1648. https://doi.org/10.1093/jn/129.9.1643

Publisher's Note Springer Nature remains neutral with regard to jurisdictional claims in published maps and institutional affiliations. 